\title{
The Digestive Lipase and Protease in the Dung Beetle, Chironitis Arrowi (Janssens)
}

\author{
A. R. Gaikwad ${ }^{1}$, G. P. Bhawane ${ }^{2}$ \\ ${ }^{1}$ Department of Zoology, Mudhoji College, Phaltan. Maharashtra, India \\ ${ }^{2}$ Department of Zoology, Shivaji University, Kolhapur. Maharashtra, India
}

\begin{abstract}
Characteristics of lipase and protease from mid gut $(M G)$ and hind gut $(H G)$ of adult dung beetle; Chironitis arrowi were studied. The $\mathrm{pH}$ maxima, the optimal temperature and $\mathrm{Km}$ of these enzymes were determined. Lipase was showing the pH maxima at 8.0, while protease interestingly showed two $\mathrm{pH}$ optima at 7.0 and 10.0 in both sexes and guts. Temperature optima for lipase were occurred at $40^{\circ} \mathrm{C}$ in both guts and sexes. However protease was showing higher temperature optima at $55^{\circ} \mathrm{C}$ in both guts of male and female. The $\mathrm{Km}$ values of lipase were $3.175 \times 10^{-4} \mathrm{M}$ and $2.413 \times 10^{-4} \mathrm{M}$ in male and female $(\mathrm{MG})$ respectively. For protease the $\mathrm{Km}$ values were $0.0312 \%$ in male $(M G)$ and $0.0357 \%$ in female $(M G)$. The $50 \%$ inhibition of lipase occurred at $50^{\circ} \mathrm{C}$ within 9.5 minutes in male $(M G)$ and 9.7 minutes in female (MG). The half life of protease at $65^{\circ} \mathrm{C}$ was occurred within 38.5 minutes and 31.50 minutes, in male and female (MG) respectively. The digestion periods of 10 minutes (for lipase in both sexes, MG) and 20 minutes (for protease in both sexes, MG) were fitted very well within the linear part of enzymatic action.
\end{abstract}

Keywords: Dung beetle, characteristics of lipase, protease enzymes, Km values, thermolability.

\section{Introduction}

The dung beetles play a vital role in natural ecosystems. Bornemissza (1960) suggested that dung beetles could help to remove dung pads in an efficient manner. Dung beetles are an important component of dung fauna. In many areas they are the dominant species present at vertebrate dung. They exhibit a wide range of ecological, morphological and behavioral adaptations that have helped them to establish in various regions of the world (Hanski and Cambefort, 1991). Chironitis arrowi a common true dung beetle found in Maharashtra. Adult dung beetles have specialized mouthparts for dung feeding (Halffter and Matthews 1966). We are presently engaging the studies related to digestive physiology of dung beetles. The adult beetles feed on the liquid and colloidal content of dung. The alimentary canal is adapted for coprophagy. The activity of most digestive enzymes is reflected with degree of adaptation to food components. Therefore, we presently have worked on protein and fat digesting enzymes of alimentary canal of Chironitis arrowi.

\section{Materials and Methods}

\subsection{Insect Collection}

The dung beetles were collected from 2 to 3 days old cattle dung pads from the grazing fields of Phaltan region, Maharashtra, India. The collected beetles were maintained in the laboratory in earthen pots.

\subsection{Preparation of Enzyme Extract}

After acclimatization the male and female beetles were sacrificed separately for preparation of mid gut (MG) and hind gut (HG) enzyme extracts. The homogenates of pooled tissues were prepared in $0.9 \%$ chilled $\mathrm{NaCl}$, which were cold, centrifuged for $15 \mathrm{~min}$. at 10,000 rpm. Aliquots of supernatants were used as enzyme source. The homogenates were stored in freezer until used.

\subsection{Lipase Assays}

The activity of lipase was measured according to Hayashi and Tappel (1970). The assay system consisted of $0.25 \% \mathrm{ml}$ emulsion of trioline in appropriate buffer, $0.25 \mathrm{ml}$ of supernatant and $1.5 \mathrm{ml}$ of appropriate buffer followed by incubation at appropriate temperature for 10 minutes using metabolic shaker. The reaction was terminated by adding 2 $\mathrm{ml}$ of ATC (mixture of acetic acid; tri-ethanol amine and copper nitrate in ratio of 1:9:1) reagent and then $10 \mathrm{ml}$ of chloroform the reaction mixture was then vigorously shaken and allowed to stand for 10 minutes. Then $2 \mathrm{ml}$ of the chloroform layer was pipette out in well stopper tube. In this tube $1.5 \mathrm{ml}$ of lipase colouring reagent $(25 \mathrm{mg}$ diphenylcarbazone and $475 \mathrm{mg}$ of diphenylcarbazide in 100 $\mathrm{ml}$ methanol) was added. The liberated free fatty acids in chloroform produce pink colour with colouring reagent, were measured colorimetrically according to Itaya (1977) at $550 \mathrm{~nm}$. The standard curve was obtained by using palmitic acid under similar assay conditions. The activity was expressed as $\mu \mathrm{g}$ palmitic acid/ $\mathrm{mg}$ protein/hr.

\subsection{Protease Assays}

The protease activity was determined by using Birk et. al. (1962) procedure as used by Ishaaya et. al. (1971).The absorbency of the reaction mixture was read as O.D. units using quartz cuvettes Hitachi U. V. spectrophotometer at $280 \mathrm{~nm}$ against a control in which the enzyme was substituted by preheated supernatant. The reaction mixture consisted of $1 \mathrm{ml}$ of $1 \%$ Caesin (Hammerstein ) prepared in appropriate $0.1 \mathrm{M}$ buffer solution and $0.5 \mathrm{ml}$ of supernatant. The reaction mixture was incubated at appropriate temperature for 20 minutes. The reaction was terminated by adding $3 \mathrm{ml}$ of $5 \% \mathrm{TCA}$. The precipitate of unreacted protein was removed by centrifugation. The supernatants thus obtained were read at $280 \mathrm{~nm}$ against the blank. The

\section{Volume 4 Issue 11, November 2015}




\section{International Journal of Science and Research (IJSR) \\ ISSN (Online): 2319-7064}

Index Copernicus Value (2013): 6.14 | Impact Factor (2014): 5.611

standard curve was obtained by using different tyrosine concentrations, keeping conditions constant. The activity was expressed in terms of $\mu \mathrm{g}$ tyrosine $/ \mathrm{mg}$ protein $/ \mathrm{hr}$.

\subsection{Thermolability}

To study the thermolability of these enzymes, the adults were dissected in $0.9 \%$ saline and their mid guts were taken out for the enzyme extract preparation. A portion of enzyme extract was immediately stored in refrigerator for control purpose. The remaining portion of enzyme extract was then subjected to high temperature treatment by keeping the test tubes containing enzyme in water bath maintained at $50^{\circ} \mathrm{C}$ (for lipase) and at $65^{\circ} \mathrm{C}$ (for protease) for different period of time. The various heat treated enzyme extracts were stored in the refrigerator, until they were used for experiment. The activities of residual enzymes left after heat treatments were determined by the procedures as described earlier for respective enzymes. The mean activities of control (without heat treatment) were taken as $100 \%$ activity of lipase and protease enzymes.

\subsection{Protein Estimation}

Lowery et.al. (1951) method was used for determining soluble protein content of the enzyme extract. Assay mixture consisted of $0.5 \mathrm{ml}$ of enzyme extract made to $1 \mathrm{ml}$ with distilled water to this $5 \mathrm{ml}$ of Lowery's ' $\mathrm{C}$ ' Solution was added. Then after 10 to 15 minutes $0.5 \mathrm{ml}$ of FolinCiocalteus regent was added. The optimal density as read at $640 \mathrm{~nm}$ after 30 minutes.

\section{Results}

The characteristics of lipase and protease in mid guts and hind guts of adult dung beetle Chironitis arrowi were studied. The results are as follows.

\subsection{Effect of $\mathrm{pH}$}

The lipase showed the maximum activity at $\mathrm{pH} 8.0$ in both sexes and guts(Gr.1), while the protease interesting showing two $\mathrm{pH}$ optima, one at $\mathrm{pH} 7.0$ and other at $\mathrm{pH} 10.5$ in both gut sections of male and female beetles(Gr.2)

\subsection{Effect of Temperature}

The lipase enzyme showed comparatively low temperature optima of $40^{\circ} \mathrm{C}$ irrespective of sexes and guts (Gr.3) while protease showed higher temperature optima of $55^{\circ} \mathrm{C}$ in both sexes and guts (Gr.4).

\subsection{Effect of Time}

The digestion period of 10 minutes was found to be fit within the linear part of enzymatic activity curve for mid gut lipase of both sexes. The digestion period of 20 minutes for protease in mid gut of both sexes was found to be fit very well within the linear part of enzymatic activity curve.

\subsection{Thermolability}

The effect of high temperature on the stability of lipase (at $50^{\circ} \mathrm{C}$ ) and protease (at $65^{\circ} \mathrm{C}$ ) were studied in mid gut sections of this dung beetle species. The $50 \%$ inhibition of lipase occurred at $50^{\circ} \mathrm{C}$ within 9.5 minutes in male (MG) and 9.7 minutes in female (MG) (Gr.5). The half life of protease at $65^{\circ} \mathrm{C}$ was occurred within 38.5 minutes and 31.50 minutes, in male and female (MG) respectively (Gr.6).

\subsection{Effect of Substrate Concentration}

The relationship between substrate (triolene for lipase and casein for protease) concentration and rate of hydrolysis of these enzymes were studied in mid and hind guts of adult $C$. arrowi .Line weaver- Burk's plots were plotted so as to obtain Michaeli's constant $(\mathrm{km})$, by using reciprocals of substrate concentration $(1 / \mathrm{S})$ and reciprocals of velocity concentration $(1 / \mathrm{V})$. Such Line weaver Burk's plots are shown in Gr.7 (for lipase) and Gr.8 (for protease). The Km values of lipase were $3.175 \times 10^{-4} \mathrm{M}$ and $2.413 \times 10^{-4} \mathrm{M}$ in male and female $(\mathrm{MG})$ respectively. For protease the $\mathrm{Km}$ values were $0.0312 \%$ in male (MG) and $0.0357 \%$ in female (MG).

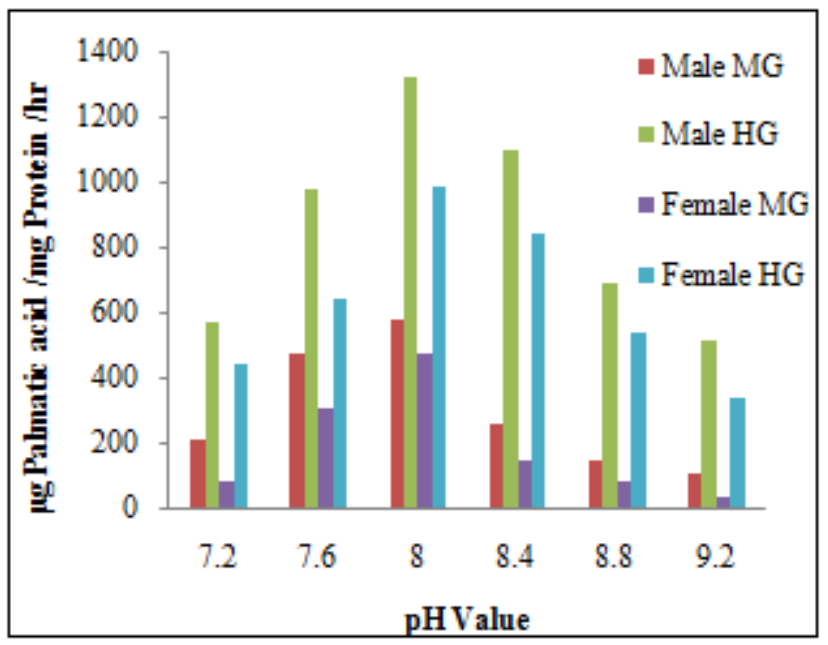

Gr.1. Effect of $\mathrm{pH}$ (Lipase)

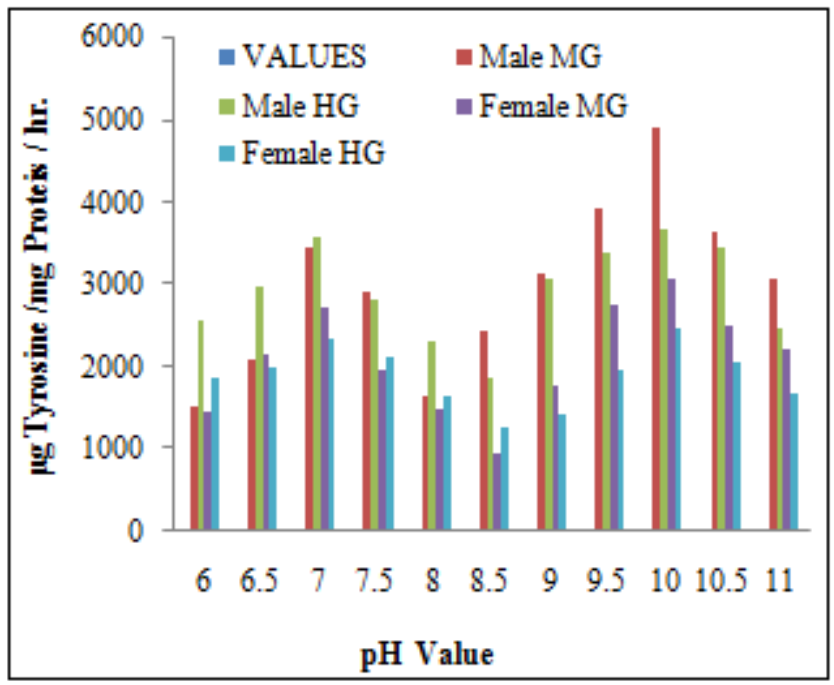

Gr.2. Effect of $\mathrm{pH}$ (Protease) 


\section{International Journal of Science and Research (IJSR) \\ ISSN (Online): 2319-7064}

Index Copernicus Value (2013): 6.14 | Impact Factor (2014): 5.611

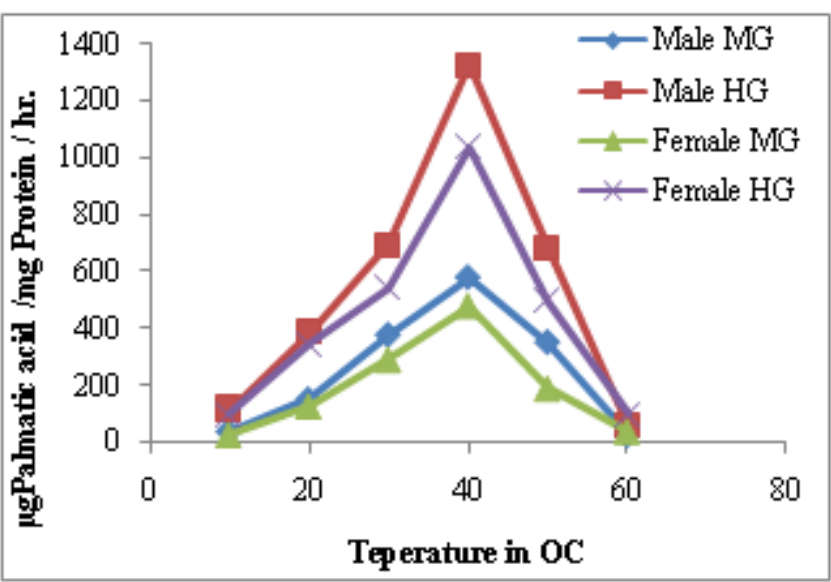

Gr.3. Effect of Temperature (Lipase)

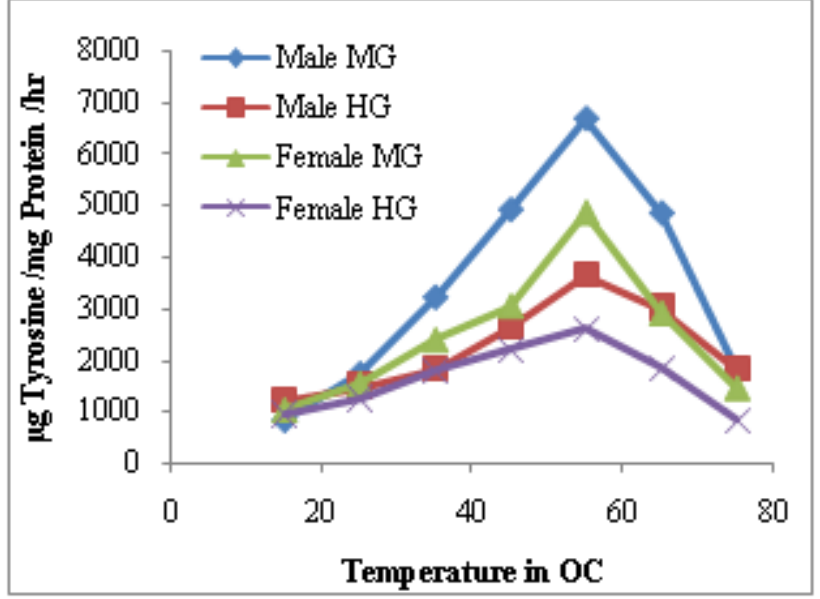

Gr.4. Effect of Temperature (Protease)
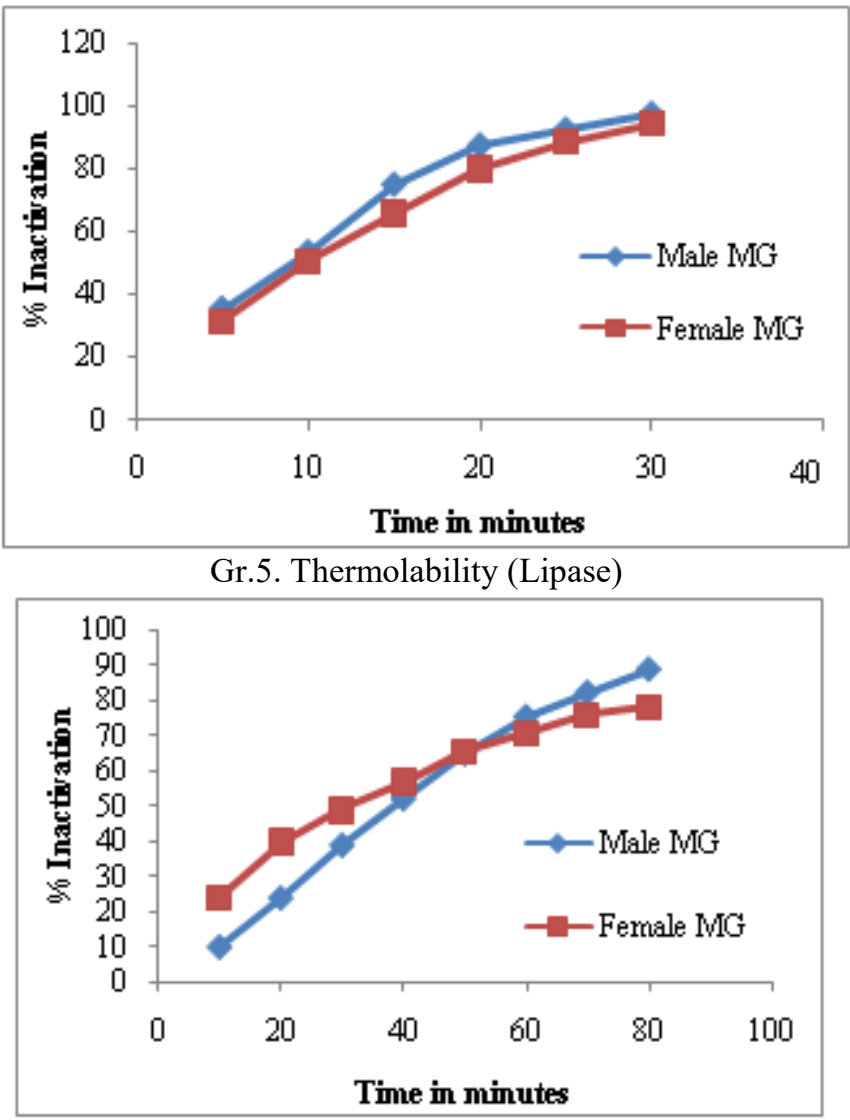

Gr.6 Thermolability (Protease)

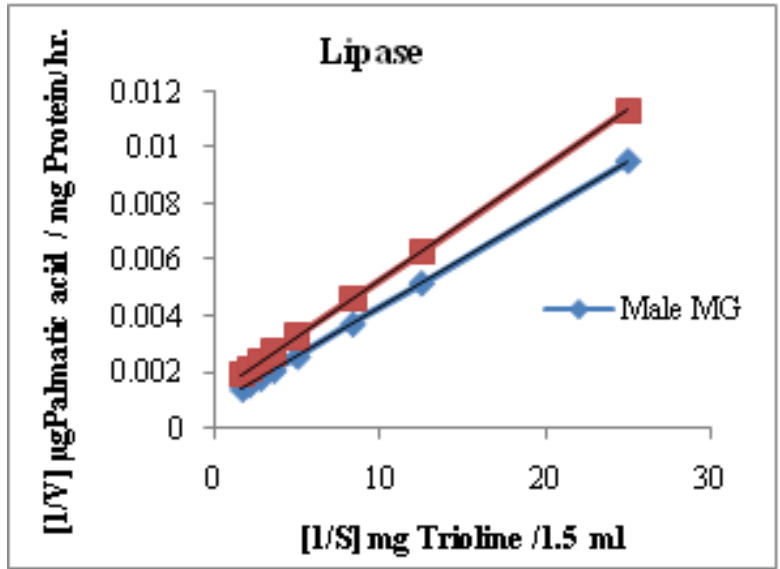

Gr.7. Line weaver Burk's plot

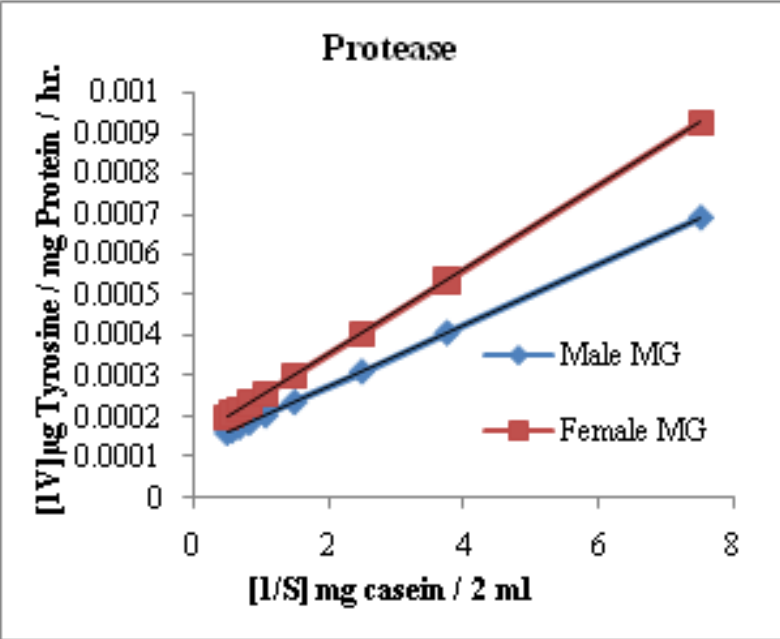

Gr.8 Line weaver Burk's plot

Male MG: $\mathrm{Y}=0.000827+0.000348 \mathrm{X}$ Male MG: $\mathrm{Y}=$ $0.0001261+0.0000749 \mathrm{X}$

Female MG: $\mathrm{Y}=0.001273+0.0004036 \mathrm{X}$ Female MG: $\mathrm{Y}=$ $0.0001481+0.0001034 \mathrm{X}$

\section{Discussion}

Lipase showed $\mathrm{pH}$ optima at 8.0 in both sexes and gut sections of alimentary canal. Similar findings were obtained for the some Scarabaeid species by earlier workers (Bhanot, 1992, Patil, 1996 and Kumbhar, 1996). Scant information exists on the insect lipase (Terra et.al., 1979; Male and Storey, 1981; Thomas and Nation, 1984; Bhawane and Bhanot, 1989; Pol and Sawant, 1990 and 1995). They reported $\mathrm{pH}$ optima in the range of 8.2 to 8.8 in the insects.

Very interestingly the protease enzymes showed two peaks of activity at two different $\mathrm{pH}$. The adults of $C$. arrowi in both gut section showed maximum activity of protease at $\mathrm{pH}$ 7.0 and 10.5 for this enzyme. Thus the enzyme protease is active either neutral or at highly alkaline $\mathrm{pH}$. Similar condition exit in the some species of Scarabaeid studied earlier (Bhanot 1992; Patil 1996 and Kumbhar 1996). Above observations indicates that there exists iso-enzymes of protease in the mid and hind guts of Scarabaeidae. But the activity of iso enzymes having $\mathrm{pH} 10.0$ more pronounced. Optimum $\mathrm{pH}$ values for the protease in most of the insect studied are either neutral or alkaline and they are found to be 


\section{International Journal of Science and Research (IJSR) \\ ISSN (Online): 2319-7064 \\ Index Copernicus Value (2013): 6.14 | Impact Factor (2014): 5.611}

slightly higher than the $\mathrm{pH}$ of gut contents, (Ishaaya, et.al., 1971; Eguchi, et, al., 1982; Eguchi and Iwamoto, 1976).

Lipase showed maximum activity at temperature $40^{\circ} \mathrm{C}$ in studied gut sections of dung beetles. Similar temperature optima for lipase were observed in some insects by Patil (1996); Pol, (1984); Pol and Sawant (1995).Temperature optima of $30^{\circ} \mathrm{C}$ was observed for the lipase in crickets by Thomas and Nation (1984). In Acheta domesticus adults the temperature optima of lipase are at $37^{\circ} \mathrm{C}$ (Teo and Woodring, 1988).

Protease showed maximum activity at Temperature $55^{\circ} \mathrm{C}$; .more or less similar temperature range was reported in other insects by Bhanot (1992); Baker (1977); Gooding ;( 1977); Gooding and House ;( 1969); Ishaaya and Swirski (1970) and Patil (1996).

Digestion period of 10 minutes was found to be fit very well within the linear part of enzymatic activity curve for lipase. Similar result was also obtained in C. orientalis (Kumbhar, 1996) and $H$ serrata (Patil, 1996) for this enzyme. The digestion period of 20 minutes was found to be fit well within the linear part of enzymatic activity curve for protease in studied dung beetle species. In other insects in which this enzyme was studied showed same digestion period (Kumbhar, 1996; Patil, 1996).

The $50 \%$ inhibition of lipase occurred at $50^{\circ} \mathrm{C}$ within 9.5 minutes in male (MG) and 9.7 minutes in female (MG). The results co-related with that of $C$. orientalis (Kumbhar, 1996); and in H. serrata Patil (1996). This indicates that lipase is most heat labile enzyme. The half life of protease at $65^{\circ} \mathrm{C}$ was occurred within 38.5 minutes and 31.50 minutes, in male and female (MG) respectively. Papin is most heat stable Proteolytic enzyme which lost of its activity after 120 min. of heat treatment at 70\% (Powing et.al.1951).

In the present dung beetle species, the $\mathrm{Km}$ values of lipase were $3.175 \times 10^{-4} \mathrm{M}$ and $2.413 \times 10^{-4} \mathrm{M}$ in male and female (MG) respectively. The $\mathrm{km}$ values for lipase of Chrysomia rufifacies $\left(4.0 \times 10^{-4} \mathrm{M}\right.$ of triolene); for Valanga $\left(2.68 \times 10^{-2}\right.$ $\mathrm{M}$ of triolene) ; for Valanga (2.68 $\times 10^{-2} \mathrm{M}$ of tributryn); for H. serrata $\left(6.284 \times 10^{-4} \mathrm{M}\right.$ and $1.5 \times 10^{-3} \mathrm{M}$ of triolene); for C. orientalis $\left(2.28 \times 10^{-4} \mathrm{M}\right.$ of triolene and $2.15 \times 10^{-4} \mathrm{M}$ of triolene) (Teo, 1973, Pol, 1984; Pol and Sawant, 1990; Patil, 1996 and Kumbhar, 1996).

Protease showing $\mathrm{km}$ values $0.0315 \%$ and $0.0357 \%$ of casein in mid gut of male and female respectively. This indicates that in $C$. arrowi protease is equally efficient in both sexes. Very little is known about the $\mathrm{km}$ values of the gut proteases in insects. In Valanga, $\mathrm{km}$ values for protease were $19.358 \mathrm{mg} / \mathrm{ml}$ for casein and $9.025 \mathrm{mg} / \mathrm{ml}$ for gelatin (Teo, 1973). The $\mathrm{km}$ vale for larval blowfly protease was $71.9 \mathrm{mg} / \mathrm{ml}$ (Evans, 1958); for larval and adult mid gut of $H$. serrata were $0.028 \%$ and $0.069 \%$ of casein respectively (Patil, 1996) and larval and adult mid gut of $C$. orientalis were $158 \%$ and $0.476 \%$ of casein respectively (Kumbhar, 1996).

The mid gut is the measure source for these digestive enzymes in this dung beetle species. These results agree with the general view that mid gut is the chief site of digestive enzyme secretion (Dadd, 1970; Law, et.al, 1977; Engelmann and Gerarets, 1980). However, hind gut also contributes significantly in the secretion of digestive enzymes in larvae and adults of the dung beetle species. This indicates that the hind gut also plays important role in the process of digestion of coprophagous larvae and adults of $O$. philemon and $O$. catta (Gaikwad, 1998). Similar results were also obtained by Thomas and Nation, (1984) in the hind gut of G. rubens and S. acletus; by Bhawane and Bhanot (1989) in hind gut of white grub, $H$. serrata by Bhanot (1992) in $L$. lepidophora larvae; by Patil, 1996 in larvae and adults of $H$. serrata by Kumbhar (1996) in larvae of C. orientalis.

\section{Acknowledgement}

Authors are grateful to the Head, Zoology Department, Shivaji University, Kolhapur for providing facilities and encouragements.

\section{References}

[1] Baker, J.E., (1977). Substrate specificity in the control of digestive enzymes in larvae of the black carpet beetle. J. Insect Physiol. 23, 749-753.

[2] Bhanot, P.K. (1992).Studies on some aspects of biology of white grubs, Ph.D.Thesis,Shivaji University, Kohlapur.

[3] Bhawane G.P. and Bhanot.R.K. (1989).Digestive Phsiology in 3rd instar Scarabaeidae larvae of Holotrichia serrata Fab. J. Zool.Soc. India.40 (1\&2):37-44.

[4] Birk, Y., Harpaz, I.,Ishaaya I. \& Bondi,A.(1962) Studies of the proteolysis activity of the beetle Tenebrio and Tribollium. J. Insect physiology. 8, 417-429

[5] Bornemissza GF. (1960). Could dung eating insects improve our pastures? Journal of the Australian

[6] Institute of Agricultural Science 26: 54-56.

[7] Dadd. R. H. (1970).Digestion in insect in: Chemical Zoology Arthropoda. Vol.5 Florkin M.,Scheer B. T.(eds):Academic press. New York, pp 117-145.

[8] Eguchi M. and Iwamoto A. (1976) Alkaline proteases in the mid gut tissue and digestive fluid of the silkworm, Bombyx mori. Insect Biochem. 6, 491-496.

[9] 8.Eguchi M., lwamoto A. and Yamauchi K. (1982) Inter- relation of proteases from the midgut lumen, epithelia and peritrophic membrane of the silkworm, Bombyx mori L. Comp. Biochem. PhysioL 72A, 359363.

[10] Engelmann, F. and Geraerts, W. P. M. (1980).The protease and the protease inhibitor in the midgut of Leucophaea madarae J. Insect Physiol. 26: 703-710.

[11] Evans W.A.L. (1958).Studies on the digestive enzymes of the blowfly Calliphora erythrocephala.II.

[12] Kinetic constants of the larval gut proteinase.Exp.Parasitol.7, 69-81

[13] Gaikwad A.R. (1998).The Biology of some dung beetles of South-Western Maharashtra Ph.D.Thesis,Shivaji University, Kolhapur.

[14] Gaikwad.A.R.; Bhawane.G.P. Patil.S.B.and Disle.S.P. (1997).Digestive enzymes of Onitis philemon(Fab.)Grub (Coleoptera:Scarabaeidae:Scarabaeinae).Recent Advances in Ecobology Research.Vol.I pp 335-357

[15] Gooding R.H. (1977).Digestive processes of haematophagous insects.XIII. Evidence For the digestive efimction of midgut proteinases of Glossina

\section{Volume 4 Issue 11, November 2015}




\section{International Journal of Science and Research (IJSR) \\ ISSN (Online): 2319-7064}

Index Copernicus Value (2013): 6.14 | Impact Factor (2014): 5.611

morsitans morsitans Westwood (Diptera: Glossinidae) Can.J. Zoo/.55, 1557-1562

[16] Gooding, R.H. (1972).Digestive proteases of haematophagous insects: a literature review. Quaest. Ent. 8, 5-60.

[17] Gooding, R.H. and House,C.T.(1969).Trypsin and chymotrypsin from the beetle, Pterostichus melanorius.J.Insect.Physiol.15:325-339.

[18] Halffter, G. and E.G. Matthews, (1966). The natural history of dung beetles of the subfamily Scarabaeinae (Coleoptera: Scarabaeidae). Folia Entomologica, Mexicana, 12-14: 1-313.

[19]Hanski, I. \& Cambefort, Y. (1991). Dung Beetle Ecology. New Jersey, Princeton University Press, 481 p.

[20] Hayashi, K. and Tappel, A. (1970).Specificity and other properties of lysosomal lipase of rat liver.J.Biol.Chem.245:169-175

[21] Ishaaya I. and Swirksi E. (1970). Invertase and amylase activity in the armoured scales, Chrysomphalus aonidum and Aonidiella auranti. J.Insect.Physiol. 16:1599-1606.

[22] Ishaaya, I.,Moorie I.\& Joseph,D.(1971)Protease andamylase activity in the larvae of the Egyptian cotton worm,Spodoptera littoralis(L). J. insects physiol., $17,945-953$

[23] Itaya, K. (1977). A more sensitive and stable colorimetric determination of free fatty acids in blood. $J$ Lipid Res. 18: 663-665.

[24] Kumbhar, S.M. (1996). The studies on digestive system of Chiloloba orientalis.M.Sc.(P.P.P.R.) Dissertation,Shivaji University,Kolhapur.

[25]Law .J.H., Dunn.P. and Krame K.J.(1977).Insect protease and peptidase In:Advances in Enzymology (Meister, A. Ex.) Vol. 5, John Wily,New York.

[26] Lowry, O.H., Rosebraugh, N. J., Farr, A. L. and Randall, R.J. (1951). Protein measurement with the Folin phenol reagent. J. Bio. Chem. $176-275$

[27] Male, K. B. and Story, K. B.(1981).Enzyme activities and isozyme composition of triglyceride, diglyceride and monoglyceride lipases in Periplaneta americana, Locusta migratoria and Polia adjuncta. Insect Biochem. 11: 25-31

[28] Patil, S.B. (1996). Studies on some systems of Holotrichia serrata (Coleoptera:Scarabaeidae).Ph.D. Thesis Shivaji University,Kohlapur.

[29] Pol, J. J. and Sawant, V. A. (1990). Studies on lypolytic activity profile of larva of Chrysomia rufifacies during larval growth. Advancesin Biosci. 9(II): 61-68.

[30] Pol, J.J. and Sawant, V. A. (1995). Lipase activity during metamorphosis of Chrysomia rufifacies. Entomon. 20(2): 51-53.

[31] Pol, J.J.1984.Studiesd on lipolytic enzymes in insect during embryogenesis, growth and metamorphosis. Ph.D. Thesis, Shivaji Unversity, Kohlapur.

[32] Powning R.F.,Day M.F.and Irzykiewicz H.(1951).Studies on digestion of woolly insects. Aust.J.Sci. Res.4B, 49-63.

[33] Teo L.H. and Woodring J.P. (1988). The digestive protease and lipase in the house cricket Acheta domesticus. Insect Biochem.18, 363-367.

[34] Teo, L. H. (1973).Comparison of the quantitative distribution and thermo stability of the digestive enzymes of Valanga migricornt (Acrididae). Nanyang University J.7.78-88

[35] Terra W.R.,Ferreira C.and De Bianchi A.G.(1979).Distribution of digestive enzymes among the endo-and ectoperitrophic spaces and mid gut cells of Rhynchosciara and its physiological significance. J.Insect Physiol.25, 487-494.

[36] Thomas.K.K.and Nation. J.K.L. (1984).Protease, amylase and lipase activities in the mid gut and hind gut of the cricket,Gryllus rubens and mole cricket, Scapteriscus acletus. Comp.Biochem.Physilogy (2):297304. 